\title{
Monitoring of mercury in the mesopelagic domain of the Pacific and Atlantic oceans using body feathers of Bulwer's petrel as a bioindicator
}

\author{
Ricardo Furtado a,* , José Pedro Granadeiro ${ }^{\mathrm{b}}$, Marie Claire Gatt ${ }^{\mathrm{b}}$, Rachel Rounds ${ }^{\mathrm{c}}$, Kazuo Horikoshi ${ }^{\mathrm{d}}$, \\ Vítor H. Paiva ${ }^{\mathrm{e}}$, Dilia Menezes ${ }^{\mathrm{f}}$, Eduarda Pereira ${ }^{\mathrm{g}}$, Paulo Catry ${ }^{\mathrm{a}}$ \\ a MARE - Marine and Environmental Sciences Centre, ISPA - Instituto Universitário, Rua Jardim do Tabaco, 1149-041 Lisboa, Portugal \\ b CESAM - Centre for Environmental and Marine Studies, Departamento de Biologia Animal, Faculdade de Ciências, Universidade de Lisboa, Campo Grande, $1749-016$ Lisboa, Portugal. \\ c Pacific Islands Refuges and Monuments Office Inventory and Monitoring Program U.S. Fish and Wildife Service, Honolulu, HI 808-792-9559, United States of America \\ d Institute of Boninology Chichijima, Ogasawara-mura, Tokyo 100-2101, Japan \\ e Universidade de Coimbra, MARE - Marine and Environmental Sciences Centre, Departamento de Ciências da Vida, Calçada Martim de Freitas, $3000-456$ Coimbra, Portugal \\ ${ }^{\mathrm{f}}$ Instituto das Florestas e Conservação da Natureza, IP-RAM, 9064-512 Funchal, Portugal \\ ${ }^{\mathrm{g}}$ Department of Chemistry and CESAM/REQUIMTE, University of Aveiro, 3810-193 Aveiro, Portugal
}

\section{H I G H L I G H T S}

- Bulwer's petrels were used as biomonitors of $\mathrm{Hg}$ levels in the mesopelagic domain.

- Atlantic colonies showed higher Hg concentrations than those from the Pacific.

- CSIA-AA-derived trophic levels for chicks were similar among colonies.

- Feather Hg levels recorded were lower than those reported in 1992 for the Atlantic.

\section{A R T I C L E I N F O}

\section{Article history:}

Received 6 October 2020

Received in revised form 6 February 2021

Accepted 7 February 2021

Available online 12 February 2021

Editor: Xinbin Feng

\section{Keywords:}

Mercury

Mesopelagic specialists

Foraging

Biomonitoring

Compound-specific stable isotope analysis

\section{G R A P H I C A L A B S T R A C T}

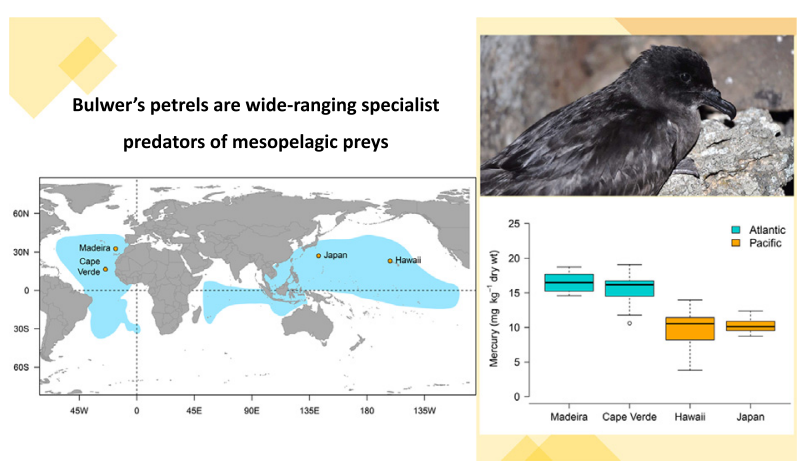

\begin{abstract}
A B S T R A C T
Global mercury pollution has markedly and consistently grown over the past 70 years (although with regional variations in trends) and is a source of major concern. Mercury contamination is particularly prevalent in biota of the mesopelagic layers of the open ocean, but these realms are little studied, and we lack a large scale picture of contamination in living organisms of this region. The Bulwer's petrel Bulweria bulwerii, a species of migratory seabird, is a highly specialised predator of mesopelagic fish and squid, and therefore can be used as a bioindicator for the mesopelagic domain. Mercury accumulated by the birds through diet is excreted into feathers during the moulting process in adults and feather growth in chicks, reflecting contamination in the non-breeding and breeding periods, respectively, and hence the influence of different, largely non-overlapping breeding and nonbreeding ranges. We studied mercury in feathers and the trophic position in two colonies from the Atlantic Ocean (Portugal and Cape Verde) and two colonies from the Pacific Ocean (Japan and Hawaii). We found significantly lower levels of mercury in adult and chick samples from the Pacific Ocean compared with samples from the Atlantic Ocean. However, we did not detect differences in trophic position of chicks among colonies and oceans, suggesting that differences in mercury measured in feathers reflect levels of environmental contamination, rather than differences in the structure of the trophic chain in different oceans. We conclude that despite a reduction in mercury levels in the Atlantic in recent decades, mesopelagic
\end{abstract}

\footnotetext{
* Corresponding author.

E-mail address: ricardomirandafg@hotmail.com (R. Furtado).
} 
organisms in this ocean remain more heavily contaminated than in the Pacific at tropical and subtropical latitudes. We suggest that Bulwer's petrel is a highly suitable species to monitor the global contamination of mercury in the mesopelagic domain.

\section{Introduction}

Global mercury pollution has markedly and consistently grown over the past 70 years (although with regional variations in trends) as a result of anthropogenic activities such as gold extraction, industrial production, waste incineration and the use of fossil fuels (Driscoll et al., 2013; Esdaile and Chalker, 2018; Gworek et al., 2016; Lamborg et al., 2014; Streets et al., 2019, 2011). Mercury is widely transported in the atmosphere and is also distributed in marine ecosystems through oceanic circulation (Driscoll et al., 2013). For pelagic ocean zones, the dominant source of mercury is atmospheric deposition (an exception is the Arctic Ocean where coastal erosion is likely the dominant source) (Obrist et al., 2018). This elemental mercury sinks adsorbed to particles and is transformed to methylmercury by biogeochemical processes in low oxygen environments, such as the mesopelagic zone (200-1000 m below the ocean surface) (Choy et al., 2009; Lamborg et al., 2014; Mason and Fitzgerald, 1991; Sunderland et al., 2009). It is in this organic form that it is biomagnified up the food chain, with top predators such as seabirds exhibiting elevated concentrations of mercury (Lavoie et al., 2013). In fact, mesopelagic fauna provide a trophic link between surface and deep waters as a result of their diel vertical migration (Kelly et al., 2019). Consequently, they also transport methylmercury into the epipelagic domain (Madigan et al., 2018; Motta et al., 2019; Thompson et al., 1998).

Top predators, such as pelagic seabirds, particularly those that feed on mesopelagic prey, are highly exposed to persistent and toxic mercury (e.g., Carravieri et al., 2018, 2020; Furtado et al., 2019, 2020; Monteiro and Furness, 1995, 1997; Kim et al., 1996). Because in-situ monitoring of the mesopelagic layer is difficult, bioindicators, as seabirds, are commonly used to monitor these ecosystems. Many biomonitoring efforts report on inter-species comparisons which may introduce other sources of variation, predominantly differences in prey type both at the inter- and intra-species level (e.g., Drevnick et al., 2015; Fleishman et al., 2019; Monteiro and Furness, 1997; Thompson et al., 1998). Some seabirds, such as the Bulwer's petrel (Bulweria bulwerii), are specialised predators of mesopelagic prey (Neves et al., 2011; Harrison et al., 1983; Spear et al., 2007; Waap et al., 2017). Their low variability in diet (Spear et al., 2007; Waap et al., 2017) and wide spatial distribution (Dias et al., 2015; Brooke, 2004) makes them ideal candidates to monitor oceanic mercury contamination over multiple ocean basins. The Bulwer's petrel is a small (ca. $100 \mathrm{~g}$ ), highly pelagic seabird with a large distribution in the tropical and subtropical waters of the world's oceans (Brooke, 2004; Dias et al., 2015; Ramos et al., 2015). In the Pacific Ocean, it breeds on Japan, the Hawaiian Islands, eastern China and French Polynesia, while in the Atlantic it breeds on the Macaronesian archipelagos of the Azores, Madeira, Canaries and Cape Verde (Brooke, 2004).

During the non-breeding season, Bulwer's petrels from Desertas and Cape Verde are mid- to long-distance migrants, moving into tropical deep, open oceanic areas in the Atlantic (Dias et al., 2015; Ramos et al., 2015). Those nesting in Hawaii and Japan migrate to central and eastern tropical Pacific waters and into the Indian Ocean (Brooke, 2004; Harrison, 1990). Outside the breeding season, the wide-ranging movements of birds from colonies from Atlantic and Pacific Ocean (e.g., Dias et al., 2015) mean that populations are sampling at an ocean-basin scale (millions of $\mathrm{km}^{2}$ ). Mercury values obtained from adult feathers are expected to largely reflect mercury exposure during the non-breeding period, when most body feathers are moulted (ca.
mid-September to March) (Furness et al., 1986; Howell, 2012; Monteiro et al., 1996; own unpublished data). On the other hand, during the breeding-season seabirds act as central place foragers, restricting provisioning trips to waters within a range of the colony to be able to regularly feed the chick (Chaurand and Weimerskirch, 1994; Granadeiro et al., 1998; Shoji et al., 2015; Wischnewski et al., 2019). GPS tracking data from Raso, Cape Verde, place the mean maximum displacement from the colony of chick-rearing Bulwer's petrels at $335 \pm$ $159 \mathrm{~km}$ (V. H. Paiva, unpublished data). Assuming similar foraging strategies across the four colonies, the chicks of Bulwer's petrels can be seen as biological samplers of a defined area (of tens of thousands of $\mathrm{km}^{2}$ ) around the breeding colonies.

Apart from geographical differences in mercury contamination, mercury levels in tissue are dependent on trophic position (Lavoie et al., 2013; Monteiro et al., 1998). Recently, compound-specific stable isotope analysis of amino acids (CSIA-AA) has been used to determine trophic position of seabirds robustly (e.g., Gagne et al., 2018; Gatt et al., 2020b; McMahon et al., 2015; Quillfeldt et al., 2017; Quillfeldt and Masello, 2020). By comparing the relative enrichment of ${ }^{15} \mathrm{~N}$ in "source" and "trophic" amino acids, typically phenylalanine and glutamic acid respectively, CSIA-AA effectively overcomes the limitations in interpreting bulk isotope ratios in oceanic taxa as a result of a poorly-defined baseline isoscape (Graham et al., 2009). Phenylalanine represents the isotope ratio of primary producers at the base of the food chain, effectively providing the isotopic baseline needed to calculate the trophic position. In contrast, glutamic acid is increasingly enriched with ${ }^{15} \mathrm{~N}$ as it undergoes nitrogen fractionation up the food chain (Ohkouchi et al., 2017). Given that Bulwer's petrels are known to be specialist predators of small mesopelagic fishes and squids (Neves et al., 2011; Spear et al., 2007; Waap et al., 2017), we could expect trophic position to be similar between colonies. If trophic positions are similar among individuals from different colonies, then variability in mercury concentrations would reflect geographical variation in mercury contamination at medium to large geographical scales.

Here, we investigate geographical differences in mercury concentration in feathers of adults and chicks of Bulwer's petrels from two Atlantic and two Pacific colonies, which reflect contamination levels in the mesopelagic domain. Furthermore, we quantified CSIA-derived trophic position in chicks to determine whether any differences in mercury exposure may be a result of trophic position. Feathers are the major sink for mercury excretion in birds, where mercury is deposited during feather growth, reflecting accumulation through diet over this period (Monteiro and Furness, 2001). As a result, quantifying mercury in feathers provides temporal and spatial contexts (Hobson, 1999; Monteiro and Furness, 1995). It is known, however, that some mercury is accumulated previous to moult, and the first feathers to be moulted display higher concentrations than the ones moulted later (Gatt et al., 2020a). Avoiding feathers that are moulted earlier (such as the inner primaries) and taking a large number of feathers minimizes and dilutes this problem. Furthermore, this problem does not affect large chicks, for which the contribution of egg mercury is likely very small and virtually all the mercury originates from diet in the well-defined period ranging from hatching to feather growth (Ackerman et al., 2011; Bearhop et al., 2000). We tested whether (a) mercury exposure in adults and chicks was significantly influenced by geographical area, and (b) whether trophic position differed significantly among chicks from different colonies and oceans. 


\section{Methods}

\subsection{Study site and sampling procedure}

We collected Bulwer's petrels feather samples during the 2018 breeding season from two colonies in the Atlantic Ocean - Deserta Grande $\left(32^{\circ} 30^{\prime} \mathrm{N} 16^{\circ} 30^{\prime} \mathrm{W}\right)$ of the Madeiran archipelago, Portugal, and Raso Islet $\left(16^{\circ} 37^{\prime} \mathrm{N} 24^{\circ} 35^{\prime} \mathrm{W}\right)$ in Cape Verde and from two colonies in the Pacific Ocean - Nihoa Island $\left(23^{\circ} 03^{\prime} \mathrm{N} ; 161^{\circ} 55^{\prime} \mathrm{W}\right)$ in Hawaii, USA, and Minami-jima Island $\left(27^{\circ} 02^{\prime} \mathrm{N} ; 142^{\circ} 10^{\prime} \mathrm{E}\right)$ in Japan (Fig. 1). The colonies sampled have similar breeding phenology (April-October) (Chiba, 2020; Cruz-Flores et al., 2018; Kohno et al., 1986; Nunes and Vicente, 1998; Whittow, 1994). Eight to ten body feathers were collected from incubating adult birds ( $\mathrm{n}=71$ in total, $15-20$ individuals per colony) and growing feathers from chicks towards the end of the chickrearing period (August-October, before fledging) ( $n=75$ in total, 15-20 individuals per colony) (Table 1 ). Feathers were clipped, in the superior umbilicus of feather, excluding the calamus, and collected from various locations on the body (dorsal and ventral; below the neck and above the lower extremities) and stored in polyethylene bags.

\subsection{Mercury analyses}

The feathers were cut into fine pieces to produce a homogeneous sample, and an electronic micro-balance (Sartorius M5P, Sartorius AG, Gottingen, with $0.001 \mathrm{mg}$ precision) was used to prepare between $0.26 \mathrm{mg}$ and $1.02 \mathrm{mg}$ (mean $=0.51 \pm 0.14 \mathrm{mg}$ ) of sample for mercury determination. We used thermal decomposition atomic absorption spectrometry with gold amalgamation in LECO AMA-254 equipment, to determine the total concentration of mercury in the body feathers (Costley et al., 2000). This procedure does not require sample pretreatment (e.g., wash), and also allows for a small sample mass to be used. Briefly, feather samples were placed in a nickel boat and covered with aluminium oxide to prevent sample dispersion. Subsequently, the boat enters a combustion tube containing a catalyst where the sample is dried at $120^{\circ} \mathrm{C}$, followed by decomposition at $850{ }^{\circ} \mathrm{C}$. Analyses were performed in triplicate per bird, blanks were analysed at the beginning of each set of samples, and the coefficient of variation between replicates never exceeded $10 \%$. Accuracy and precision were assured by the daily analysis of five readings of a certified reference material (CRM) lobster hepatopancreas TORT-3 (Lobster hepatopancreas from the National Research Council of Canada; certified mercury concentration: $0.292 \pm 0.022 \mathrm{mg} \mathrm{kg}^{-1} \mathrm{dw}$ ). The obtained values (mean $\pm \mathrm{SD}$ ) for the TORT-3 analyses ranged from 75 to $90 \%$ (recovery efficiencies of $82.72 \pm 3.38 \%, n=17$ ), results were corrected using the daily recovery efficiency of CRM. The mass of TORT-3 used for quality control analyses was adjusted to be within the range of total mercury (in ng) present in the samples, with a maximum coefficient of variation of $10 \%$. The limit of detection for this analytical method is $0.01 \mathrm{ng} \mathrm{g}^{-1}$ of total mercury. Mercury concentrations in feathers are presented in $\mathrm{mg} \mathrm{kg}^{-1}$ fresh weight.

\subsection{Compound-specific isotope analysis of amino acids}

Collected feather samples were homogenized, as in the analysis of mercury, and sent to the Stable Isotope Facility at the University of California, Davis, for CSIA-AA of ${ }^{15} \mathrm{~N}$ following calibration techniques detailed in Walsh et al. (2014) and Yarnes and Herszage (2017). Amino acids first underwent acid hydrolysis $\left(6 \mathrm{M} \mathrm{HCl}, 70 \mathrm{~min}, 150{ }^{\circ} \mathrm{C}\right.$ under a $\mathrm{N}_{2}$ headspace) before derivatization as $\mathrm{N}$-acetyl methyl esters. These derivatives were injected at $260{ }^{\circ} \mathrm{C}$ (splitless, $1 \mathrm{~min}$ ) and separated on a polar gas chromatography column (Agilent DB-35) and combusted at a constant flow rate of $2 \mathrm{~mL} / \mathrm{min}$ under the following temperature program: $70{ }^{\circ} \mathrm{C}$ (hold $\left.2 \mathrm{~min}\right) ; 140{ }^{\circ} \mathrm{C}\left(15^{\circ} \mathrm{C} \min ^{-1}\right.$, hold $\left.4 \mathrm{~min}\right)$; $240{ }^{\circ} \mathrm{C}\left(12{ }^{\circ} \mathrm{C} \mathrm{min}^{-1}\right.$, hold $\left.5 \mathrm{~min}\right)$; and $255^{\circ} \mathrm{C}\left(8{ }^{\circ} \mathrm{C} \mathrm{min}^{-1}\right.$, hold $35 \mathrm{~min})$. GC-C-IRMS was performed on a Thermo Trace GC 1310 gas chromatograph linked to a Thermo Scientific Delta V Advantage isotope-ratio mass spectrometer via a GC IsoLink II combustion interface. The combustion reactor is a $\mathrm{NiO}$ tube containing $\mathrm{CuO}$ and $\mathrm{NiO}$ wires maintained at $1000{ }^{\circ} \mathrm{C}$. Water is subsequently removed through a Nafion dryer before the analyte gases are transferred to the IRMS. During ${ }^{15} \mathrm{~N}$ analysis, $\mathrm{CO}_{2}$ is removed from the post-combustion carrier stream through the use of a liquid nitrogen trap to prevent isobaric interferences within the ion source. Samples were analysed in duplicate, and triplicate measurements were recorded when average standard deviation exceeded $\pm 1 \%$. Final quality assessment was based on the accuracy and precision of unbiased quality control materials, which included a calibrated amino acid mixture, UCD AA3, and multiple natural materials (fish skin gelatin reference material, whale baleen reference material and shark muscle reference material).

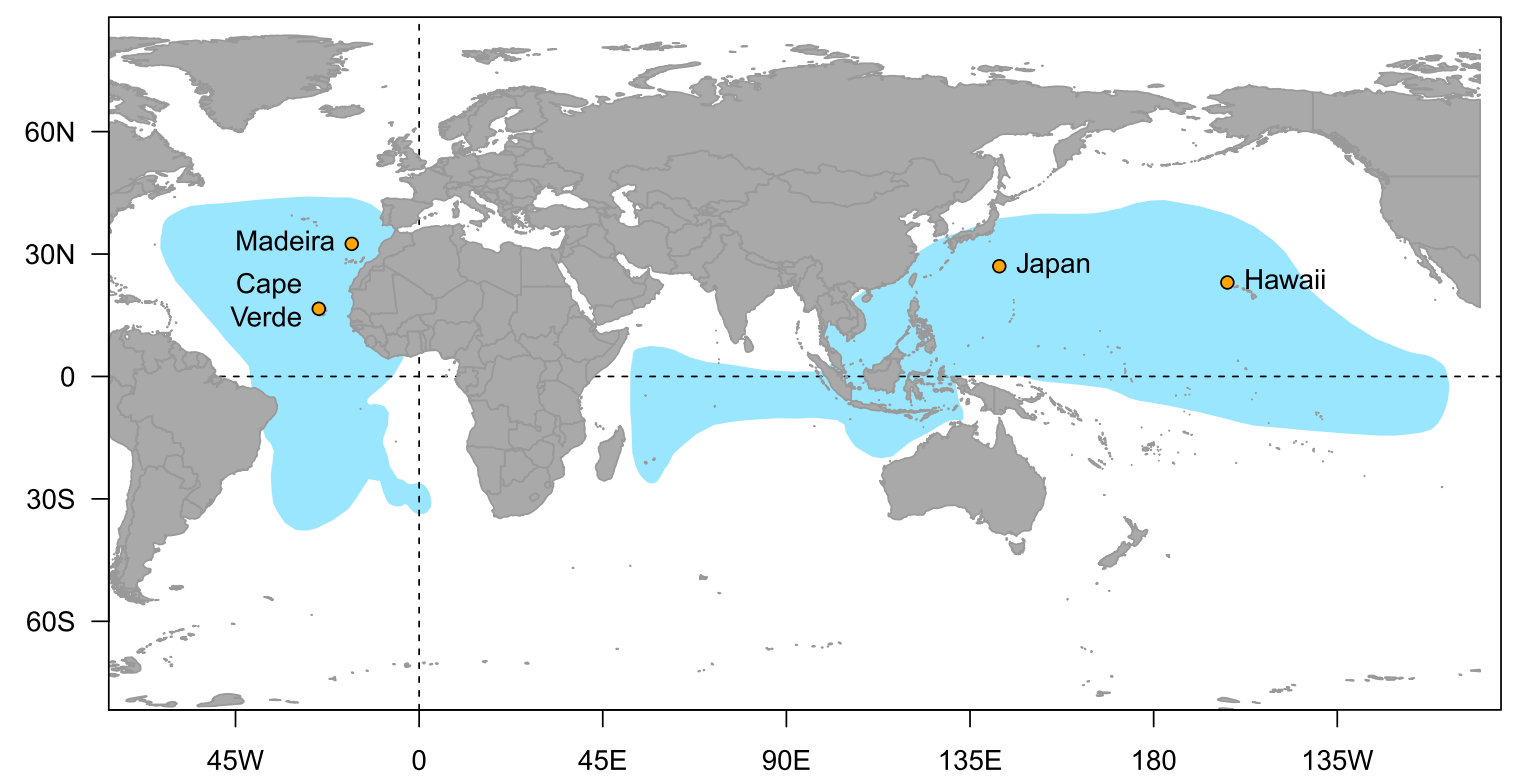

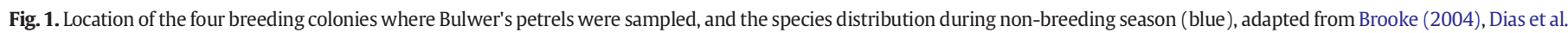
(2015) and Ramos et al. (2015). (For interpretation of the references to colour in this figure legend, the reader is referred to the web version of this article.) 
Table 1

Mercury concentration in feathers of adults and chicks of Bulwer's petrel (mean \pm SD and range, $\mathrm{mg} \mathrm{kg}^{-1}$ fresh wt).

\begin{tabular}{|c|c|c|c|c|c|}
\hline \multirow[t]{2}{*}{ Age } & \multirow[t]{2}{*}{ Ocean } & \multirow[t]{2}{*}{ Colony } & \multicolumn{2}{|l|}{$[\mathrm{Hg}] \mathrm{mg} \mathrm{kg}^{-1}$} & \multirow[t]{2}{*}{ Number of samples } \\
\hline & & & Mean \pm SD & Range & \\
\hline \multirow[t]{4}{*}{ Chicks } & Atlantic Ocean & Cape Verde & $5.11 \pm 1.76$ & $2.70-9.96$ & 15 \\
\hline & & Madeira & $4.38 \pm 1.69$ & $2.94-8.25$ & 20 \\
\hline & Pacific Ocean & Japan & $2.13 \pm 0.38$ & $1.44-3.17$ & 20 \\
\hline & & Hawaii & $2.90 \pm 0.84$ & $1.81-5.21$ & 20 \\
\hline \multirow[t]{4}{*}{ Adults } & Atlantic Ocean & Cape Verde & $15.65 \pm 2.22$ & 10.61-19.09 & 20 \\
\hline & & Madeira & $16.49 \pm 1.39$ & $14.60-18.76$ & 20 \\
\hline & Pacific Ocean & Japan & $10.27 \pm 1.11$ & 8.74-12.39 & 15 \\
\hline & & Hawaii & $10.00 \pm 2.55$ & $3.80-13.97^{\mathrm{a}}$ & 15 \\
\hline
\end{tabular}

a An outlier was removed $\left(21.8 \mathrm{mg} \mathrm{kg}^{-1}\right)$.

\subsection{Calculating trophic positions}

Trophic position of chicks (Table 2 ) was calculated from the nitrogen stable isotope values $\left(\delta^{15} \mathrm{~N}\right)$ of glutamic acid (Glx) and phenylalanine (Phe). Including multiple trophic discrimination factors $\left(\mathrm{TDF}_{\mathrm{Glx}-\mathrm{Phe}}\right)$ in the estimation of trophic position, to integrate the span of the trophic web, produces more robust results, calculated as follows:

$T P=2+\frac{G l x-P h e-3.5-3.4}{6.2}$

where $6.2 \%$ is the trophic discrimination factor for trophic position at the base of the aquatic food chain $\left(\Delta_{\text {herbivore}}\right)$ (McMahon and McCarthy, 2016), 3.5\% is the trophic discrimination factor for seabird feathers $\left(\Delta_{\text {carnivore }}\right)$, and $3.4 \%$ is the difference in $\delta{ }^{15} \mathrm{~N}$ between glutamic acid and phenylalanine in primary producers $(\beta)$ (McMahon and McCarthy, 2016; Ohkouchi et al., 2017; Quillfeldt and Masello, 2020). To take into account both analytical and ecological variation, the uncertainty in trophic position was calculated by propagation of errors (Ohkouchi et al., 2017):

$$
\begin{aligned}
\sigma_{\mathrm{TP}}^{2}= & \left(\frac{1}{\Delta_{\text {carnivore }}}\right)^{2} \sigma_{\delta 15 \mathrm{~N}(\mathrm{Glx})}^{2}+\left(\frac{-1}{\Delta_{\text {carnivore }}}\right)^{2} \sigma_{\delta 15 \mathrm{~N}(\text { Phe })}^{2} \\
& +\left(\frac{1}{\Delta_{\text {carnivore }}}\right)^{2} \sigma_{\beta}^{2}+\left(\frac{-1}{\Delta_{\text {carnivore }}}\right)^{2} \sigma_{\Delta_{\text {carnivore }}}^{2} \\
& +\left\{\frac{-1}{\Delta_{\text {carnivore }}^{2}}\left(\delta^{15} \mathrm{~N}_{\mathrm{Glx}}-\delta^{15} \mathrm{~N}_{\text {Phe }}+\beta-\Delta_{\text {herbivore }}\right)\right\}^{2} \sigma_{\text {herbivore }}^{2}
\end{aligned}
$$

where $\sigma_{\Delta \text { carnivore }}$ and $\sigma_{\Delta \text { herbivore }}$ are estimated at $0.4 \%$ (McMahon et al., 2015 ) and $1.4 \%$ (Chikaraishi et al., 2007) respectively, and $\sigma_{\beta}$ is $0.9 \%$ (Chikaraishi et al., 2009).

\subsection{Statistical analysis}

All statistical analyses were carried out with R statistical software ( $R$ Core Team, 2020). The means of mercury concentrations are presented with standard deviations. Mercury concentrations in feathers of adults from Hawaii showed a wide range of values, from 3.80 to $23.61 \mathrm{mg} \mathrm{kg}^{-1}$, with the latter value being considered an outlier. We removed this outlier, but note that retaining it does not qualitatively

Table 2

CSIA-AA-derived trophic position analysed from body feathers of chicks of Bulwer's petrel.

\begin{tabular}{lllll}
\hline Ocean & Colony & \begin{tabular}{l} 
Trophic position \\
\cline { 3 - 4 }
\end{tabular} & $\begin{array}{l}\text { Mean } \pm \text { propagated } \\
\text { error }\end{array}$ & $\begin{array}{l}\text { Rumber of } \\
\text { samples }\end{array}$ \\
& & $3.37 \pm 0.33$ & $3.24-3.58$ & 6 \\
\hline Atlantic Ocean & Cape Verde & $3.35 \pm 0.33$ & $3.19-3.47$ & 6 \\
& Madeira & 3.35 & $3.22-3.60$ & 6 \\
Pacific Ocean & Japan & $3.36 \pm 0.33$ & $3.32-3.56$ & 6 \\
& Hawaii & $3.45 \pm 0.30$ & & \\
\hline
\end{tabular}

change any results and statistical conclusions. To compare the mean feather mercury concentrations of adults and chicks among geographical areas, we used ANOVA, followed by Tukey post hoc tests. We used analysis of variance (one-way ANOVA) to compare the trophic position of chicks in the different breeding areas, after checking for data normality. We also use Welch's t-tests for simple comparisons where appropriate.

\section{Results}

We found significant differences in mercury levels among breeding colonies of Bulwer's petrel for adults (ANOVA: $F_{3,67}=56.6, p<0.001$ ) and chicks (ANOVA: $F_{3,71}=20.79, p<0.001$ ). Post-hoc Tukey tests indicated that Bulwer's petrels from the Atlantic Ocean had higher feather mercury levels than those from the Pacific Ocean (adults - Atlantic Ocean: $16.07 \pm 1.88 \mathrm{mg} \mathrm{kg} \mathrm{kg}^{-1}$ and Pacific Ocean: $10.12 \pm$ $1.94 \mathrm{mg} \mathrm{kg}^{-1}$; chicks - Atlantic Ocean: $4.70 \pm 1.73 \mathrm{mg} \mathrm{kg}^{-1}$ and Pacific Ocean: $2.52 \pm 0.75 \mathrm{mg} \mathrm{kg}^{-1}$ ), with no difference between colonies in the same ocean basin (Atlantic Ocean: ANOVA: $\mathrm{F}_{1,73}=0.25, \mathrm{p}=$ 0.619 and Pacific Ocean: ANOVA: $\mathrm{F}_{1,68}=0.11, \mathrm{p}=0.745$ ).

There were no significant differences in the trophic position of chicks among colonies (Table 2) (ANOVA: $\mathrm{F}_{3,20}=0.81, \mathrm{p}=0.50$ ). Propagated errors associated with trophic position, determined by Eq. (b), were all $<0.45$ (mean $=0.32$ ), indicating the precision of this method.

Previous studies of mercury in ventral whole feathers of adult Bulwer's Petrels from the Madeiran archipelago, collected from 1992 to 1994 , report a concentration of $21.6 \pm 0.7 \mathrm{mg} \mathrm{kg}^{-1}$ (mean $\pm \mathrm{SE}$ ) (range 12.20-33.80 $\mathrm{mg} \mathrm{kg}^{-1}, \mathrm{n}=55$ ) (Monteiro and Furness, 1997). These values are significantly higher than those obtained in this study for the colony of Deserta Grande, Madeira (mean \pm SE: $16.49 \pm$ $0.31 \mathrm{mg} \mathrm{kg}^{-1}$ (range 14.16-18.76 $\mathrm{mg} \mathrm{kg}^{-1}, \mathrm{n}=20$ )) (Welch's t-test: $t=6.7, \mathrm{df}=69, \mathrm{p}<0.0001)$.

\section{Discussion}

We evaluated the concentration of mercury in Bulwer's petrels' feathers from four colonies across the Atlantic and Pacific Oceans. To our knowledge, this is the first single-species study to assess mercury in birds mostly relying on the mesopelagic domain at the tropics and sub-tropics on a scale of multiple ocean basins.

The diet of Bulwer's Petrel in the Pacific Ocean has been studied in the north-western Hawaiian Islands (Harrison et al., 1983), analysing induced or spontaneous regurgitates, and in the open sea (eastern tropical Pacific Ocean), through the analysis of stomach contents of birds shot for research purposes (Spear et al., 2007). The diet, in the Atlantic Ocean, was studied in the Azores archipelago, analysing induced regurgitates (Neves et al., 2011) and in the Madeiran Archipelago through DNA barcoding, using regurgitations of chicks (Waap et al., 2017). These studies showed that Bulwer's petrels forage almost exclusively on mesopelagic fish (mainly Myctophidae, Gonostomatidae, Phosichthyidae, Sternoptychidae, Centriscidae, Melamphaidae, Macrouridae and 
Melanonidae) and squid (mainly Ommastrephidae, Histioteuthidae, Mastigoteuthidae, Chiroteuthidae and Cranchiidae) (Neves et al., 2011; Harrison et al., 1983; Spear et al., 2007; Waap et al., 2017). The similarity in trophic position of chicks from different colonies across two oceans reported here strongly suggests that the trophic niche and foraging strategies in Bulwer's petrel are highly conserved across geographies. Moreover, the high, but similar across locations, mercury concentrations in adult Bulwer's petrels from the same oceans reinforce the idea that Bulwer's petrels are specialist predators year-round, with a diet based on mesopelagic preys in both the non-breeding and the breeding seasons, irrespective of colony location. Furthermore, adult Bulwer's petrels from Hawaii, sampled in 2010, appear to occupy a similar trophic position (ca. 3.8) to that of chicks of Bulwer's petrel from Hawaii (ca. 3.5), sampled in this study (Gagne et al., 2018). Together, these results identify the Bulwer's petrel as an ideal monitor of mercury bioavailability in different geographic areas in the oceans. Similarities in mercury exposure in adults from the Japanese and Hawaiian colonies also suggest that they spend the non-breeding period in broadly overlapping oceanic areas, as do Bulwer's petrels from different breeding ranges in the Atlantic (Ramos et al., 2015), or that the mesopelagic preys within the Pacific basin have similar mercury concentrations.

Adults and chicks of Bulwer's petrels from Atlantic colonies had significantly higher (ca. 59\% in adults and ca. $86 \%$ in chicks) mercury concentrations than those from the Pacific Ocean. Given that trophic differences are not apparent, the most likely explanation for this is that mesopelagic fish and squid in the Atlantic have higher mercury levels as compared to the Pacific, resulting from different bioavailability of methylmercury in mesopelagic zones (e.g., Becker et al., 2016; Carravieri et al., 2014). Such large variation in mercury concentrations of mesopelagic species between the Atlantic and Pacific oceans may arise from a complex interplay of factors, which include among others, variation in atmospheric deposition, variation in productivity and microbial activity, and differences in plankton communities, as different types of phytoplankton display highly distinct bioaccumulation rates (Zhang et al., 2020). Our findings are in accordance with previous investigations reporting higher mercury concentrations in deep water in the mesopelagic domain in the Central South Atlantic (ca. $1.3 \pm 0.62 \mathrm{pM}$ in the South Atlantic) than in the central and eastern Pacific (ca. $0.61 \pm$ $0.19 \mathrm{pM}$ in the Central South Pacific and $0.59 \pm 0.25 \mathrm{pM}$ in the Eastern Tropical Pacific) (Gill and Fitzgerald, 1988; Bowman et al., 2020).

Mercury concentrations in the North Atlantic waters appear to have decreased during the last several decades, likely due to reduced atmospheric deposition (Bowman et al., 2015; Cossa et al., 2012; Obrist et al., 2018). Such reduction in mercury deposition or mercury concentrations in ocean waters are thought to be driving the declines detected in time series of mercury contamination in Bluefish (Pomatomus saltatrix; Cross et al., 2015) and Atlantic bluefin tuna (Thunnus thynnus; Lee et al., 2016) in the northwest Atlantic, and in Striped dolphins (Stenella coeruleoalba) in the Mediterranean (Borrell et al., 2014). Our results, when compared to those of Monteiro and Furness (1997) for Bulwer's petrels are perfectly in line with the above findings and further support the existence of a decline from 1992 to 2018 . We note that our methodological approach was slightly different from the one adopted by Monteiro and Furness (1997), as they used whole feathers while we excluded the calamus. Given that the calamus has lower mercury concentrations than the rachis and the vane (Peterson et al., 2019), we would expect, all other things being equal, that our mercury measurements would be slightly higher than those in the former study (note that the calamus only represents ca. $11 \%$ of the feather mass; Peterson et al., 2019). The fact that more recent samples had lower, not higher, mercury concentrations reinforces our conclusions. However, we recognise that measurements in 2 points in time cannot substitute a complete time-series to detect a temporal trend. Data from the Pacific show an increase in mercury bioavailability (Drevnick et al., 2015). However, in many cases the temporal trends in marine biota do not faithfully parallel changes in atmospheric inputs (Wang et al., 2019), due the slow transport of mercury into lower ocean levels where it is transformed to methylmercury and assimilated by organisms (Driscoll et al., 2013).

Studies on broad spatial and temporal trends in oceanic mercury concentrations often compare data from tuna species (Drevnick et al., 2015; Houssard et al., 2019; Lee et al., 2016; Manhães et al., 2020). However, given that tuna are widely recognised as opportunistic generalist top predators, feeding facultatively on both epipelagic and mesopelagic prey (Duffy et al., 2017; Olafsdottir et al., 2016), their mercury exposure may reflect the confounding effects of environmental contaminant levels, layers in the ocean where they feed (epi- or mesopelagic) and trophic position (Gatt et al., 2020b). Bulwer's petrel feathers could complement the current monitoring in intermediate waters without the difficulties of quantifying and interpreting the influence of trophic position, which seems to be similar in both oceans.

Our observation that chicks bore lower mercury concentration than adults is in agreement with similar comparisons in other seabird taxa (Becker et al., 2002; Tavares et al., 2013). This is attributed to the shorter period of time during which mercury is accumulated in the body through the diet in chicks before they are able to excrete it into growing feathers (Bustamante et al., 2016; Furness et al., 1986; Thompson et al., 1998).

Mercury concentrations in body feathers of adult Bulwer's petrels are higher than those in many other seabirds (e.g., Furtado et al., 2019; Monteiro et al., 1999), comparable to concentrations found in some large albatross species (Thompson et al., 1993). Such high concentrations reflect the Bulwer's petrel's dependency on mesopelagic prey. Mercury concentrations between 5 and $40 \mathrm{mg} \mathrm{kg}^{-1}$ in feathers of waterbirds have been reported by some studies to carry negative impacts on reproductive parameters or survival (Scheuhammer et al., 2007; Whitney and Cristol, 2017; Wolfe et al., 1998). However, most research suggests that seabirds exhibit extraordinary resistance to mercury contamination (Carravieri et al., 2018, 2020; Gilmour et al., 2019; Wolfe et al., 1998), with the highest concentrations recorded at $95 \mathrm{mg} \mathrm{kg}^{-1}$ in an adult male Wandering Albatross (Diomedea exulans) with no obvious impacts to its fitness (Bustamante et al., 2016).

\subsection{Conclusions}

Our results suggest that, given the similarity in trophic position across the two oceans, and its wide-ranging foraging behaviour, the Bulwer's petrel provides an integrated measure of mercury contamination in the tropical and sub-tropical mesopelagic domain at the scale of multiple ocean basins. Results suggest that birds in the Atlantic Ocean are currently exposed to higher mercury concentrations than those in the Pacific Ocean, reflecting higher contamination in fish and squid of the mesopelagic compartment of the Atlantic Ocean. Results also suggest that mercury levels in the oceanic waters of the tropical/subtropical Atlantic Ocean have declined over the past 2-3 decades, but more data are needed to further confirm this trend. The use of body feathers provides an accessible and non-invasive method for such monitoring. The exceptionally high concentration of mercury in Bulwer's petrels warrants further research to determine potential detrimental effects on behaviour, reproductive success or survival.

\section{Funding source}

Thanks are due for the financial support to CESAM (UIDB/50017/ 2020 and UIDP/50017/2020), MARE (UIDB/04292/2020 and UIDP/ $04292 / 2020$ ), and doctoral grant $\mathrm{PD} / \mathrm{BD} / 127807 / 2016$ awarded to MCG, attributed by the Foundation for Science and Technology (FCT; Portugal).

\section{CRediT authorship contribution statement}

PC and JPG conceptualised the study and acquired funding, RF planned the methodology and drafted the manuscript, RR, KH, VHP, 
DM collected the samples. RF, JPG and MCG, compiled and analysed the data. RF, JPG, MCG and PC led the writing - review of the manuscript. PC, JPG and EP supervised the work. All authors contributed critically to revisions. All authors have read the submitted version of the manuscript and approve its submission.

\section{Declaration of competing interest}

The authors declare that they have no known competing financial interests or personal relationships that could have appeared to influence the work reported in this paper.

\section{Acknowledgments}

We are grateful to all the fieldworkers who assisted us with this research, Ana Barbosa for her contribution in the mercury analysis, and Chris Yarnes for helpful direction regarding the CSIA-AA analysis. Procedures were approved by ISPA's Ethical Committee for Animal Welfare and carried out under licenses and permits issued by the Florestas e da Conservação da Natureza (Madeira), U.S. Fish and Wildlife Service USFWS (permit number MB99493C-0), Papahānaumokuākea Marine National Monument (permit number PMNM-2018-028), Wildlife Division, Kanto Regional Environment Office, Ministry of the Environment Government of Japan (permit number 1807271) and Direção Geral de Alimentação e Veterinária - DGAV (FAX number 85/ DSECI/DIM/2018, 87/DSECI/DIM/2018 and 100/DSECI/DIM/2018).

\section{References}

Ackerman, J.T., Eagles-Smith, C.A., Herzog, M.P., 2011. Bird mercury concentrations change rapidly as chicks age: toxicological risk is highest at hatching and fledging. Environ. Sci. Technol. 45, 5418-5425. https://doi.org/10.1021/es200647g.

Bearhop, S., Ruxton, G.D., Furness, R.W., 2000. Dynamics of mercury in blood and feathers of great skuas. Environ. Toxicol. Chem. 19, 1638-1643.

Becker, P.H., González-Solís, J., Behrends, B., Croxall, J.P., 2002. Feather mercury levels in seabirds at South Georgia: influences of trophic position, sex and age. Mar. Ecol. Prog. Ser. 243, 261-269. https://doi.org/10.3354/meps243261.

Becker, P.H., Goutner, V., Ryan, P.G., González-Solís, J., 2016. Feather mercury concentrations in Southern Ocean seabirds: variation by species, site and time. Environ. Pollut. 216, 253-263. https://doi.org/10.1016/j.envpol.2016.05.061.

Borrell, A., Aguilar, A., Tornero, V., Drago, M., 2014. Concentrations of mercury in tissues of striped dolphins suggest decline of pollution in Mediterranean open waters. Chemosphere 107, 319-323. https://doi.org/10.1016/j.chemosphere.2013.12.076.

Bowman, K.L., Hammerschmidt, C.R., Lamborg, C.H., Swarr, G., 2015. Mercury in the North Atlantic Ocean: the U.S. GEOTRACES zonal and meridional sections. Deep. Sea Res. Part II Top. Stud. Oceanogr. 116, 251-261. https://doi.org/10.1016/j.dsr2.2014.07.004.

Bowman, K.L., Lamborg, C.H., Agather, A.M., 2020. A global perspective on mercury cycling in the ocean. Sci. Total Environ. 710, 136166. https://doi.org/10.1016/j. scitotenv.2019.136166.

Brooke, M., 2004. Albatrosses and Petrels Across the World. Oxford University Press, Oxford.

Bustamante, P., Carravieri, A., Goutte, A., Barbraud, C., Delord, K., Chastel, O., Weimerskirch, H., Cherel, Y., 2016. High feather mercury concentrations in the wandering albatross are related to sex, breeding status and trophic ecology with no demographic consequences. Environ. Res. 144, 1-10. https://doi.org/10.1016/j. envres.2015.10.024.

Carravieri, A., Cherel, Y., Blévin, P., Brault-favrou, M., Chastel, O., Bustamante, P., 2014 Mercury exposure in a large subantarctic avian community. Environ. Pollut. 190, 51-57. https://doi.org/10.1016/j.envpol.2014.03.017.

Carravieri, A., Fort, J., Tarroux, A., Cherel, Y., Love, O.P., Prieur, S., Brault-Favrou, M. Bustamante, P., Descamps, S., 2018. Mercury exposure and short-term consequences on physiology and reproduction in Antarctic petrels. Environ. Pollut. https://doi.org/ 10.1016/j.envpol.2017.11.004.

Carravieri, A., Bustamante, P., Labadie, P., Budzinski, H., Chastel, O., Cherel, Y., 2020. Trace elements and persistent organic pollutants in chicks of 13 seabird species from Antarctica to the subtropics. Environ. Int. 134. https://doi.org/10.1016/j. envint.2019.105225.

Chaurand, T., Weimerskirch, H., 1994. The regular alternation of short and long foraging trips in the blue petrel Halobaena caerulea: a previously undescribed strategy of food provisioning in a pelagic seabird. J. Anim. Ecol. 63, 275. https://doi.org/ $10.2307 / 5546$.

Chiba, Y., 2020. Seabird predation by an insular subspecies of the common buzzard Buteo Buteo Toyoshimai on Minamijima, Ogasawara Islands. Jap. J. Ornithol. 69, 75-90.

Chikaraishi, Y., Kashiyama, Y., Ogawa, N.O., Kitazato, H., Ohkouchi, N., 2007. Metabolic control of nitrogen isotope composition of amino acids in macroalgae and gastropods: implications for aquatic food web studies. Mar. Ecol. Prog. Ser. 342, 85-90. https://doi.org/10.3354/meps342085.
Chikaraishi, Y., Ogawa, N.O., Kashiyama, Y., Takano, Y., Suga, H., Tomitani, A., Miyashita, H. Kitazato, H., Ohkouchi, N., 2009. Determination of aquatic food-web structure based on compound-specific nitrogen isotopic composition of amino acids. Limnol. Oceanogr. Methods 7, 740-750. https://doi.org/10.4319/lom.2009.7.740.

Choy, C., Popp, B., Kaneko, J., Drazen, J., 2009. The influence of depth of mercury levels in pelagic fishes and their prey. Proc. Natl. Acad. Sci. 106, 13865-13869.

R Core Team, 2020. R: A Language and Environment for Statistical Computing. R Foundation for Statistical Computing, Vienna, Austria URL:. https://www.R-project.org/.

Cossa, D., Knoery, J., Boye, M., Marusczak, N., Thomas, B., Courau, P., Sprovieri, F., 2020. Oceanic mercury concentrations on both sides of the Strait of Gibraltar decreased between 1989 and 2012. Anthropocene, 29 https://doi.org/10.1016/j. ancene.2019.100230.

Costley, C.T., Mossop, K.F., Dean, J.R., Garden, L.M., Marshall, J., Carroll, J., 2000. Determination of mercury in environmental and biological samples using pyrolysis atomic absorption spectrometry with gold amalgamation. Anal. Chim. Acta 405, 179-183.

Cross, F.A., Evans, D.W., Barber, R.T., 2015. Decadal declines of mercury in adult bluefish (1972-2011) from the mid-Atlantic coast of the U.S.A. Environ. Sci. Technol. 49, 9064-9072. https://doi.org/10.1021/acs.est.5b01953.

Cruz-Flores, M., Militão, T., Ramos, R., Gonzalez-Solis, J., 2018. Using marine isoscapes to infer movements of oceanic migrants: the case of Bulwer's petrel, Bulweria bulwerii, in the Atlantic Ocean. PLoS One 13, 1-13. https://doi.org/10.1371/journal. pone.0198667.

Dias, M.P., Alho, M., Granadeiro, J.P., Catry, P., 2015. Wanderer of the deepest seas: migratory behaviour and distribution of the highly pelagic Bulwer's petrel. J. Ornithol. 156, 955-962. https://doi.org/10.1007/s10336-015-1210-9.

Drevnick, P.E., Lamborg, C.H., Horgan, M.J., 2015. Increase in mercury in Pacific yellowfin tuna. Environ. Toxicol. Chem. 34, 931-934. https://doi.org/10.1002/etc.2883.

Driscoll, C.T., Mason, R.P., Chan, H.M., Jacob, D.J., Pirrone, N., 2013. Mercury as a global pollutant: sources, pathways, and effects. Environ. Sci. Technol. 47, 4967-4983. https:// doi.org/10.1021/es305071v.

Duffy, L.M., Kuhnert, P.M., Pethybridge, H.R., Young, J.W., Olson, R.J., Logan, J.M., Goñi, N Romanov, E., Allain, V., Staudinger, M.D., Abecassis, M., Choy, C.A., Hobday, A.J., Simier, M., Galván-Magaña, F., Potier, M., Ménard, F., 2017. Global trophic ecology of yellowfin, bigeye, and albacore tunas: understanding predation on micronekton communities at ocean-basin scales. Deep. Sea Res. Part II Top. Stud. Oceanogr. 140, 55-73. https://doi.org/10.1016/j.dsr2.2017.03.003.

Esdaile, L.J., Chalker, J.M., 2018. The mercury problem in artisanal and small-scale gold mining. Chem. Eur. J. 24, 6905-6916. https://doi.org/10.1002/chem.201704840.

Fleishman, A.B., Orben, R.A., Kokubun, N., Will, A., Paredes, R., Ackerman, J.T., Takahashi, A., Kitaysky, A.S., Sha, S.A., 2019. Wintering in the Western Subarctic Pacific increases mercury contamination of Red-Legged Kittiwakes. Environ. Sci. Technol. 53, 13398-13407. https://doi.org/10.1021/acs.est.9b03421.

Furness, R.W., Muirhead, S.J., Woodburn, M., 1986. Using bird feathers to measure mercury in the environment: relationships between mercury content and moult. Mar. Pollut. Bull. 17, 27-30.

Furtado, R., Pereira, M.E., Granadeiro, J.P., Catry, P., 2019. Body feather mercury and arsenic concentrations in five species of seabirds from the Falkland Islands. Mar. Pollut. Bull. 149. https://doi.org/10.1016/j.marpolbul.2019.110574.

Furtado, R., Granadeiro, J.P., Campioni, L., Silva, M., Pereira, E., Catry, P., 2020. Trace elements' reference levels in blood of breeding black-browed albatrosses Thalassarche melanophris from the Falkland Islands. Environ. Sci. Pollut. Res. 27, 39265-39273. https://doi.org/10.1007/s11356-020-09928-1.

Gagne, T.O., David Hyrenbach, K., Hagemann, M.E., Van Houtan, K.S., 2018. Trophic signatures of seabirds suggest shifts in oceanic ecosystems. Sci. Adv. 4, eaao3946. doi: https://doi.org/10.1126/sciadv.aao3946.

Gatt, M.C., Furtado, R., Granadeiro, P., Lopes, D., Pereira, E., Catry, P., 2020a. Untangling causes of variation in mercury concentration between flight feathers. Environ. Pollut. https://doi.org/10.1016/j.envpol.2020.116105.

Gatt, M.C., Reis, B., Granadeiro, J.P., Pereira, E., Catry, P., 2020b. Generalist seabirds as biomonitors of ocean mercury: the importance of accurate trophic position assignment. Sci. Total Environ. 740, 140159. https://doi.org/10.1016/j. scitotenv.2020.140159.

Gill, G.A., Fitzgerald, W.F., 1988. Vertical mercury distributions in the oceans. Geochim. Cosmochim. Acta 52, 1719-1728. https://doi.org/10.1016/0016-7037(88)90240-2.

Gilmour, M.E., Lavers, J.L., Lamborg, C., Chastel, O., Kania, S.A., Shaffer, S.A., 2019. Mercury as an indicator of foraging ecology but not the breeding hormone prolactin in seabirds. Ecol. Indic. 103, 248-259. https://doi.org/10.1016/j.ecolind.2019.04.016.

Graham, B.S., Koch, P.L., Newsome, S.D., McMahon, K.W., Aurioles, D., 2009. Using isoscapes to trace the movements and foraging behavior of top predators in oceanic ecosystems. In: West, J., Bowen, G.J., Dawson, T.E., Tu, K.P. (Eds.), Isoscapes: Understanding Movement, Pattern and Process on Earth Through Isotope Mapping. Springer, New York, pp. 299-318.

Granadeiro, J.P., Nunes, M., Silva, M.C., Furness, R.W., 1998. Flexible foraging strategy of Cory's shearwater, Calonectris diomedea, during the chick-rearing period. Anim. Behav. 56, 1169-1176. https://doi.org/10.1006/anbe.1998.0827.

Gworek, B., Bemowska-Kałabun, O., Kijeńska, M., Wrzosek-Jakubowska, J., 2016. Mercury in marine and oceanic waters - a review. Water Air Soil Pollut. 227. https://doi.org/ 10.1007/s11270-016-3060-3.

Harrison, C.S., 1990. Seabirds of Hawaii: Natural History and Conservation. Cornell University Press, Ithaca.

Harrison, C.S., Hida, T.S., Seki, M.P., 1983. Hawaiian seabird feeding ecology. Wildl. Monogr. 47, 3-71.

Hobson, K.A., 1999. Tracing origins and migration of wildlife using stable isotopes: a review. Oecologia. 120, 314-326.

Houssard, P., Point, D., Tremblay-Boyer, L., Allain, V., Pethybridge, H., Masbou, J., Ferriss, B.E., Baya, P.A., Lagane, C., Menkes, C.E., Letourneur, Y., Lorrain, A., 2019. A model of 
mercury distribution in tuna from the western and central Pacific Ocean: influence of physiology, ecology and environmental factors. Environ. Sci. Technol. 53, 1422-1431. https://doi.org/10.1021/acs.est.8b06058.

Howell, S.N.G., 2012. Petrels, Albatrosses, and Storm-petrels of North America: A Photographic Guide.

Kelly, T.B., Davison, P.C., Goericke, R., Landry, M.R., Ohman, M.D., Stukel, M.R., 2019. The importance of mesozooplankton diel vertical migration for sustaining a mesopelagic food web. Front. Mar. Sci. 6, 1-18. https://doi.org/10.3389/fmars.2019.00508.

Kim, E.Y., Murakami, T., Saeki, K., Tatsukawa, R., 1996. Mercury levels and its chemical form in tissues and organs of seabirds. Arch. Environ. Contam. Toxicol. 30, 259-266. https://doi.org/10.1007/s002449900035.

Kohno, H., Abe, N., Mano, T., 1986. The seabirds of Nakanokami-shima, South Ryukyu, Japan. J. Yamashina Inst. Ornithol. 18, 1-27.

Lamborg, C.H., Hammerschmidt, C.R., Bowman, K.L., Swarr, G.J., Munson, K.M., Ohnemus, D.C., Lam, P.J., Heimbürger, L.E., Rijkenberg, M.J.A., Saito, M.A., 2014. A global ocean inventory of anthropogenic mercury based on water column measurements. Nature 512, 65-68. https://doi.org/10.1038/nature13563.

Lavoie, R.A., Jardine, T.D., Chumchal, M.M., Kidd, K.A., Campbell, L.M., 2013. Biomagnification of mercury in aquatic food webs: a worldwide meta-analysis. Environ. Sci. Technol. 47, 13385-13394. https://doi.org/10.1021/es403103t.

Lee, C.S., Lutcavage, M.E., Chandler, E., Madigan, D.J., Cerrato, R.M., Fisher, N.S., 2016. Declining mercury concentrations in bluefin tuna reflect reduced emissions to the North Atlantic Ocean. Environ. Sci. Technol. 50, 12825-12830. https://doi.org/ 10.1021/acs.est.6b04328.

Madigan, D.J., Li, M., Yin, R., Baumann, H., Snodgrass, O.E., Dewar, H., Krabbenhoft, D.P., Baumann, Z., Fisher, N.S., Balcom, P., Sunderland, E.M., 2018. Mercury stable isotopes reveal influence of foraging depth on mercury concentrations and growth in Pacific bluefin tuna. Environ. Sci. Technol. 52, 6256-6264. https://doi.org/10.1021/acs. est.7b06429.

Manhães, B.M.R., Picaluga, A. de S., Bisi, T.L., Azevedo, A.F., Torres, J.P.M., Malm, O., LailsonBrito, J., 2020. Tracking mercury in the southwestern Atlantic Ocean: the use of tuna and tuna-like species as indicators of bioavailability. Environ. Sci. Pollut. Res. 27, 6813-6823. https://doi.org/10.1007/s11356-019-07275-4.

Mason, R.P., Fitzgerald, W.F., 1991. Mercury speciation in open Ocean waters. Water, Air, Soil Pollut. 56 56, 779-789.

McMahon, K.W., McCarthy, M.D., 2016. Embracing variability in amino acid $\delta^{15} \mathrm{~N}$ fractionation: mechanisms, implications, and applications for trophic ecology. Ecosphere 7, 1-26. https://doi.org/10.1002/ecs2.1511.

McMahon, K.W., Polito, M.J., Abel, S., Mccarthy, M.D., Thorrold, S.R., 2015. Carbon and nitrogen isotope fractionation of amino acids in an avian marine predator, the gentoo penguin (Pygoscelis papua). Ecol. Evol. 5, 1278-1290. https://doi.org/10.1002/ ece3.1437.

Monteiro, L.R., Furness, R.W., 1995. Seabirds as monitors of mercury in the marine environment. Water Air Soil Pollut. 80, 851-870.

Monteiro, L.R., Furness, R.W., 1997. Accelerated increase in mercury contamination in North Atlantic mesopelagic food chains as indicated by time series of seabird feathers. Environ. Toxicol. Chem. 16, 2489-2493. https://doi.org/10.1002/etc.5620161208.

Monteiro, L.R., Furness, R.W., 2001. Kinetics, dose-response, and excretion of methylmercury in free-living adult Cory's shearwaters. Environ. Sci. Technol. 35, 739-746. https://doi.org/10.1021/es000114a.

Monteiro, L.R., Ramos, J.A., Furness, R.W., Del Nevo, A.J., 1996. Movements, morphology, breeding, molt, diet and feeding of seabirds in the Azores. Waterbirds 19, 82-97. https://doi.org/10.2307/1521810.

Monteiro, L.R., Granadeiro, J.P., Furness, R.W., 1998. Relationship between mercury levels and diet in Azores seabirds. Mar. Ecol. Prog. Ser. 166, 259-265. https://doi.org/ 10.3354/meps166259

Monteiro, L.R., Granadeiro, J.P., Furness, R.W., Oliveira, P., 1999. Contemporary patterns of mercury contamination in the Portuguese Atlantic inferred from mercury concentrations in seabird tissues. Mar. Environ. Res. 47, 137-156. https://doi.org/10.1016/ S0141-1136(98)00110-X

Motta, L.C., Blum, J.D., Johnson, M.W., Umhau, B.P., Popp, B.N., Washburn, S.J., Drazen, J.C., Benitez-Nelson, C.R., Hannides, C.C.S., Close, H.G., Lamborg, C.H., 2019. Mercury cycling in the North Pacific Subtropical Gyre as revealed by mercury stable isotope ratios. Glob. Biogeochem. Cycles 33, 777-794. https://doi.org/10.1029/2018GB006057.

Neves, V.C., Nolf, D., Clarke, M.R., 2011. Diet of Bulwer's petrel (Bulweria bulwerii) in the Azores, NE Atlantic. Waterbirds 34, 357-362. https://doi.org/10.1675/063.034.0310.

Nunes, M., Vicente, L., 1998. Breeding cycle and nestling growth of Bulwer's petrel on the Desertas Islands, Portugal. Waterbirds 21, 198-204. https://doi.org/10.2307/ 1521906.

Obrist, D., Kirk, J.L., Zhang, L., Sunderland, E.M., Jiskra, M., Selin, N.E., 2018. A review of global environmental mercury processes in response to human and natural perturbations: changes of emissions, climate, and land use. Ambio 47, 116-140. https://doi. org/10.1007/s13280-017-1004-9.

Ohkouchi, N., Chikaraishi, Y., Close, H.G., Fry, B., Larsen, T., Madigan, D.J., McCarthy, M.D., McMahon, K.W., Nagata, T., Naito, Y.I., Ogawa, N.O., Popp, B.N., Steffan, S., Takano, Y. Tayasu, I., Wyatt, A.S.J., Yamaguchi, Y.T., Yokoyama, Y., 2017. Advances in the application of amino acid nitrogen isotopic analysis in ecological and biogeochemical studies. Org. Geochem. 113, 150-174. https://doi.org/10.1016/j.orggeochem.2017.07.009.
Olafsdottir, D., MacKenzie, B.R., Chosson-P, V., Ingimundardottir, T., 2016. Dietary evidence of mesopelagic and pelagic foraging by atlantic bluefin tuna (Thunnus thynnus L.) during autumn migrations to the Iceland Basin. Front. Mar. Sci. 3. doi:https://doi. org/10.3389/fmars.2016.00108.

Peterson, S.H., Ackerman, J.T., Toney, M., Herzog, M.P., 2019. Mercury concentrations vary within and among individual bird feathers: a critical evaluation and guidelines for feather use in mercury monitoring programs. Environ. Toxicol. Chem. 38, 1164-1187. https://doi.org/10.1002/etc.4430.

Quillfeldt, P., Masello, J.F., 2020. Compound-specific stable isotope analyses in Falkland Islands seabirds reveal seasonal changes in trophic positions. BMC Ecol. 20 (21), 1-12. https://doi.org/10.1186/s12898-020-00288-5.

Quillfeldt, P., Thorn, S., Richter, B., Nabte, M., Coria, N., Masello, J.F., Massaro, M., Neves, V.C., Libertelli, M., 2017. Testing the usefulness of hydrogen and compound-specific stable isotope analyses in seabird feathers: a case study in two sympatric Antarctic storm-petrels. Mar. Biol. 164, 1-7. https://doi.org/10.1007/s00227-017-3224-8.

Ramos, R., Sanz, V., Militão, T., Bried, J., Neves, V.C., Biscoito, M., Phillips, R.A., Zino, F., González-Solís, J., 2015. Leapfrog migration and habitat preferences of a small oceanic seabird, Bulwer's petrel (Bulweria bulwerii). J. Biogeogr. 42, 1651-1664. https://doi. org/10.1111/jbi.12541.

Scheuhammer, A.M., Meyer, M.W., Sandheinrich, M.B., Murray, M.W., 2007. Effects of environmental methylmercury on the health of wild birds, mammals, and fish. Ambio 36, 12-18. https://doi.org/10.1579/0044-7447(2007)36[12:EOEMOT]2.0.CO;2.

Shoji, A., Aris-Brosou, S., Fayet, A., Padget, O., Perrins, C., Guilford, T., 2015. Dual foraging and pair coordination during chick provisioning by Manx shearwaters: empirical evidence supported by a simple model. J. Exp. Biol. 218, 2116-2123. https://doi.org/ 10.1242/jeb.120626.

Spear, L.B., Ainley, D.G., Walker, W.A., 2007. Foraging dynamics of seabirds in the eastern tropical Pacific Ocean. Stud. Avian Biol. 1-99.

Streets, D.G., Devane, M.K., Lu, Z., Bond, T.C., Sunderland, E.M., Jacob, D.J. 2011. All-time releases of mercury to the atmosphere from human activities. Environ. Sci. Technol. 45, 10485-10491. https://doi.org/10.1021/es202765m.

Streets, D.G., Horowitz, H.M., Lu, Z., Levin, L., Thackray, C.P., Sunderland, E.M., 2019. Global and regional trends in mercury emissions and concentrations, 2010-2015. Atmos. Environ. 201, 417-427. https://doi.org/10.1016/j.atmosenv.2018.12.031.

Sunderland, E.M., Krabbenhoft, D.P., Moreau, J.W., Strode, S.A., Landing, W.M., 2009. Mercury sources, distribution, and bioavailability in the North Pacific Ocean: insights from data and models. Glob. Biogeochem. Cycles 23, 1-14. https://doi.org/10.1029/ 2008 GB003425.

Tavares, S., Xavier, J.C., Phillips, R.A., Pereira, M.E., Pardal, M.A., 2013. Influence of age, sex and breeding status on mercury accumulation patterns in the wandering albatross Diomedea exulans. Environ. Pollut. 181, 315-320. https://doi.org/10.1016/j. envpol.2013.06.032.

Thompson, D., Furness, R., Monteiro, L, 1998. Seabirds as biomonitors of mercury inputs to epipelagic and mesopelagic marine food chains. Sci. Total Environ. 213, 299-305.

Thompson, D.R., Furness, R.W., Lewis, S.A., 1993. Temporal and spatial variation in mercury concentrations in some albatrosses and petrels from the sub-Antarctic. Polar Biol. 13, 239-244. https://doi.org/10.1007/BF00238759.

Waap, S., Symondson, W.O.C., Granadeiro, J.P., Alonso, H., Serra-Goncalves, C., DIas, M.P., Catry, P., 2017. The diet of a nocturnal pelagic predator, the Bulwer's petrel, across the lunar cycle. Sci. Rep. 7, 1-10. https://doi.org/10.1038/s41598-017-01312-3.

Walsh, R.G., He, S., Yarnes, C.T., 2014. Compound-specific $\delta^{13} \mathrm{C}$ and $\delta^{15} \mathrm{~N}$ analysis of amino acids: a rapid, chloroformate-based method for ecological studies. Rapid Commun. Mass Spectrom. 28, 96-108. https://doi.org/10.1002/rcm.6761.

Wang, F., Outridge, P., Xinbin, F., Bo, M., Heimbürger, L.-E., Mason, R., 2019. How closely do mercury trends in fish and other aquatic wildlife track those in the atmosphere? - implications for evaluating the effectiveness of the Minamata Convention. Sci. Total Environ. 674, 58-70.

Whitney, M.C., Cristol, D.A., 2017. Impacts of sublethal mercury exposure on birds: a detailed review. Rev. Environ. Contam. Toxicol. 244, 113-163. https://doi.org/10.1007/ 398.

Whittow, G.C., 1994. Incubation biology and nestling growth of Bulwer's petrels on Manana Island, Oahu, Hawaii. Pac. Sci. 48, 136-144.

Wischnewski, S., Arneill, G.E., Bennison, A.W., Dillane, E., Poupart, T.A., Hinde, C.A. Jessopp, M.J., Quinn, J.L., 2019. Variation in foraging strategies over a large spatial scale reduces parent-offspring conflict in Manx shearwaters. Anim. Behav. 151, 165-176. https://doi.org/10.1016/j.anbehav.2019.03.014.

Wolfe, M.F., Schwarzbach, S., Sulaiman, R.A., 1998. Effects of mercury on wildlife: a comprehensive review. Environ. Toxicol. Chem. 17, 146-160.

Yarnes, C.T., Herszage, J., 2017. The relative influence of derivatization and normalization procedures on the compound-specific stable isotope analysis of nitrogen in amino acids. Rapid Commun. Mass Spectrom. 31, 693-704. https://doi.org/10.1002/ rcm.7832.

Zhang, Y., Soerensen, A.L., Schartup, A.T., Sunderland, E.M., 2020. A global model for methylmercury formation and uptake at the base of marine food webs. Glob. Biogeochem. Cycles 34, 0-3. doi:https://doi.org/10.1029/2019GB006348. 